\title{
A path analysis study of factors influencing decubitus in a geriatric nursing home: a preliminary study
}

\author{
AGUS SANTOSA ${ }^{A-G}$, NANDA PUSPITASARI ${ }^{\mathrm{B}, \mathrm{F}, \mathrm{G}}$, NUR ISNAINII, E-G \\ ORCID ID: 0000-0002-1535-8406 \\ Department of Medical-Surgical Nursing Health Faculty, Universitas Muhammadiyah Purwokerto, Indonesia
}

A - Study Design, B - Data Collection, C - Statistical Analysis, D - Data Interpretation, E - Manuscript Preparation, F - Literature Search, G - Funds Collection

Summary Background. 33.3\% of the elderly who stayed and were treated at a geriatric nursing home in Dewanata, Cilacap, Indonesia, experienced decubitus. Nutritional status, length of bed rest, inappropriate use of mattresses, immobilization, and skin moisture due to frequent incontinence are considered to be a factor influencing the high incidence of decubitus in this area.

Objectives. The study aims to analyze the effect of nutritional status and bed rest on pressure, humidity, and friction and its effect on decubitus.

Material and methods. This case-control study involved 30 respondents who experienced decubitus as a case group and 30 respondents as a control group with no decubitus. Nutritional status, bed rest, pressure, humidity, and friction were observed and measured one by one through standard instruments. Data were analyzed by path analysis. Furthermore, the results were selected as a model to obtain an overview of the correlation between variables.

Results. There was a direct effect of nutritional status $\left(p_{2 \times 1}:-0.347\right)$ and duration of bed rest $\left(p_{2 \times 2}: 0.347\right)$ toward decubitus incidents, and there was an indirect effect of nutritional status and bed rest on decubitus incidents by pressure factor $\left(p_{Y_{12}}: 0.327\right)$, humidity $\left(p_{\mathrm{Y} 2 \mathrm{z}}:\right.$ $0.264)$ and friction $\left(p_{\mathrm{Y}_{3}}: 0.230\right)$.

Conclusions. Nutritional status and bed rest have an effect on pressure, humidity, and friction, which increases the incidence of decubitus in older people who stay in a geriatric nursing home.

Key words: geriatric nursing, nutritional status, bed rest, friction, pressure ulcer.

Santosa A, Puspitasari N, Isnaini N. A path analysis study of factors influencing decubitus in a geriatric nursing home: a preliminary study. Fam Med Prim Care Rev 2020; 22(1): 67-70, doi: https://doi.org/10.5114/fmpcr.2020.92508.

\section{Background}

The decubitus is still a significant and complicated health problem in hospitals and other public health services, one of which is in the geriatric nursing home. Incidences of decubitus have risen in the aging population, especially in those with disabilities [1]. In general, a study illustrated that the prevalence of decubitus in patients administered to the hospital was $18.96 \%$, women put at the highest incidence, while men [2].

In Indonesia, there is no national data on decubitus prevalence rates. However, several studies conducted in several hospitals and other public health services in several cities in Indonesia discovered the prevalence of decubitus ranged from $3.6-10 \%[3,4]$. The incidences of decubitus occurred mostly in the elderly group. The elderly presented a greater risk to suffer from decubitus due to several factors, such as various chronic diseases, nutritional factors, immobilization, tissue ischemia, reduction of sensory perception, friction, sleep position shifts and caregiver factors [5-7].

30 (33.3\%) out of 90 elderly who lived and were treated in the geriatric nursing home in Dewanata, Cilacap, Indonesia, experienced decubitus. The highest incident occurred in the elderly who experienced immobilization problem. Immobilization causes the elderly to rest for long periods of time, resulting in lengthy stress on certain body tissues. Skin moisture due to urine exposure in the elderly who experienced immobilization also stimulated the risk of decubitus [8].

Mattress materials selected in the geriatric nursing home in Dewanata, Cilacap, Indonesia, were also considered as a factor which caused a high incidence of decubitus here. Not all el- derly who lived and were treated in the geriatric nursing home in Dewanata, Cilacap, Indonesia, utilized a special mattress for decubitus prevention because this health service belonged to the government, which had limited funds and budget. Inappropriate mattresses, such as those with a rough and hard surface, increase pressure and friction on the skin, thereby stimulating the incidence of decubitus $[9,10]$. Poor nutritional status often experienced by the elderly could also raise the risk of decubitus, and the study revealed that poor nutrition could accelerate decubitus [11].

Based on the factors thought to be the cause of the high number of decubitus in the geriatric nursing home, Dewanata, Cilacap, Indonesia. This study aims to analyze the pathways that cause decubitus in the elderly in this place. Thus, a solution can be immediately to reduce the number of decubitus events in that place or other geriatric nursing homes.

\section{Objectives}

This study aims to analyze the effect of nutritional status and bed rest on pressure, humidity and friction, and its effect on the incidence of decubitus in older people in the geriatric nursing home in Dewanata, Cilacap, Indonesia.

\section{Material and methods}

\section{Study design}

The design of this study was a case-control study. 


\section{Study location and respondents}

This study was conducted in the geriatric nursing home in Dewanata, Cilacap, Indonesia, in May-October 2018. The population in this study was all older people living in the geriatric nursing home in Dewanata, Cilacap, Indonesia. The sample selected in this study was decubitus elderly $(n=30)$ and non-decubitus patients $(n=30)$ as a control group.

\section{Variable and measurements}

The variables studied were nutrition (X1) and the duration of bed rest (X2) as exogenous variables, while pressure (Y1), humidity ( $\mathrm{Y} 2)$, and friction ( $\mathrm{Y} 3$ ) were endogenous and intervening variables. An incidence of decubitus (Z) was selected as an endogenous variable or the effect [12].

The Body Mass Index (BMI) of all respondents was calculated to determine their nutritional status (malnutrition $<18.5$ $\mathrm{kg} / \mathrm{m}^{2}$; normal nutrition: $18.5-24.9 \mathrm{~kg} / \mathrm{m}^{2}$; over nutrition: $>25$ $\mathrm{kg} / \mathrm{m}^{2}$ ) [13], then, observed an average bed rest per day. Body pressure on the bed of respondents was also measured using a sphygmomanometer mattress (low pressure: 6-12 $\mathrm{mm} \mathrm{Hg}$; moderate pressure: $13-20 \mathrm{~mm} \mathrm{Hg}$; high pressure: $21-32 \mathrm{~mm}$ $\mathrm{Hg}$ ) [14]. Skin moisture was calculated via a digital moisture monitor for skin ( $\leq 33 \%$ : very dry skin; 34-37\%: dry skin; 38$-42 \%$ : normal skin; $43-50 \%$ : moist skin) [15]. The friction variable was measured through friction tools modified from the Braden Scale (Mild, Moderate, and Hard friction) [16].

\section{Statistical analysis}

The analysis implemented was path analysis, which was a further section of regression analysis [17-19]. To assess the feasibility of the data, prerequisite tests were conducted, such as normality, multicollinearity, linearity, and autocorrelation. The result of the residual plot analysis discovered that the data was normally distributed. The result of multicollinearity analysis illustrated that there was no multicollinearity problem (the standard error was less than one); thus, the test results were considered to be reliable. The result of the ANOVA linearity test obtained a value of $p<0.001$; thus, the data was regarded to be linear, and the results of the residual analysis indicated no autocorrelation.

\section{Model fit evaluation}

The preliminary assessment showed a good fit $\left(\chi^{2} / d f=2 ; \mathrm{CFI}\right.$ $=0.98$, RMSEA $=0.04)$. Root mean square error of approximation (RMSEA) values of less than 0.05 showed a positive fit to the template [20]. The Comparative Fit Index (CFI) is regarded to be marginal and a good fit with values higher than 0.90 [21]. The relative chi-square (CMIN/DF) is used to evaluate the model fit because it depends heavily on the sample size. A value of less than 3 is an acceptable fit [22].

\section{Ethical consideration}

This study was approved by the Health Research Ethics Committee of Universitas Muhammadiyah Purwokerto, Reg. No.: KEPK/UMP/9/V/2018, and obtained research permission from the geriatric social service nursing home in Dewanata, Cilacap, Indonesia, under No.: 028/071/2018. All respondents signed an informed consent form. All patient data was guaranteed confidential and was only used for research purposes. The researchers did not provide incentives to the respondents.

\section{Results}

The respondents in both the case and control groups amounted to $75 \%$ female, ranging from 57 to 90 years of age (70.4 \pm 7.9 ). $30 \%$ of the respondents suffered from malnutrition, while $20 \%$ experienced over nutrition. The duration of bed rest of the respondent varied between 7-21 hours/day, and most of the respondents in the case group lay in bed for more than 10 hours/day.

The results of the calculation of body pressure average on the bed ware $18.2 \pm 5.1 \mathrm{~mm} \mathrm{Hg}$, with a minimum pressure of $9 \mathrm{~mm}$ $\mathrm{Hg}$ and a maximum of $30 \mathrm{~mm} \mathrm{Hg}$. Only $13.3 \%$ of respondents obtained normal skin moisture, while $53.3 \%$ had dry skin, and $33.3 \%$ of the respondents had moist skin. On friction variable calculation, most respondents suffered from moderate friction (45\%), and $40 \%$ of the respondents experienced a risk of hard friction, with only $15 \%$ of the respondents showing a minimum risk of friction.

The results of the study revealed that nutritional status significantly affected the pressure $\left(p_{\mathrm{y} 1 \mathrm{x}}: 0.650\right)$, but there was no significant effect on moisture, and friction $\left(p_{\mathrm{Y} 2 \times 1}:-0.094 ; p_{\mathrm{Y} 3 \times 1}\right.$ : $0.036)$. The duration of bed rest significantly affected pressure $\left(p_{\mathrm{Y} 1 \times 2}: 0.446\right)$, humidity $\left(p_{\mathrm{Y} 2 \times 2}: 0.870\right)$ and friction $\left(p_{\mathrm{Y} 3 \times 2}: 0.762\right)$. The pressure was related to humidity and friction $\left(r_{\mathrm{Y} 1 \mathrm{Y} 2}: 0.447\right.$; $\left.r_{Y_{113}}: 0.549\right)$, and humidity was related to friction $\left(r_{\mathrm{Y}_{2 \gamma Y}}: 0.595\right)$.

Nutritional status had a direct effect on the incidence of decubitus $\left(p_{z \times 1}:-0.347\right)$, and this negative relationship indicated that the lower the nutritional status, the greater the risk of decubitus. The duration of bed rest had a direct effect on the incidence of decubitus $\left(p_{z \times 2}: 0.347\right)$, meaning that the longer the bed rest, the higher the risk of decubitus. Nutritional status and duration of bed rest also indirectly affected the incidence of decubitus through pressure $\left(p_{\mathrm{y} 12}: 0.327\right)$, humidity $\left(p_{\mathrm{y} 22}: 0.264\right)$, and friction $\left(p_{\mathrm{y}_{32}}: 0.230\right)$. The structural results of the path analysis model can be seen in Figure 1.

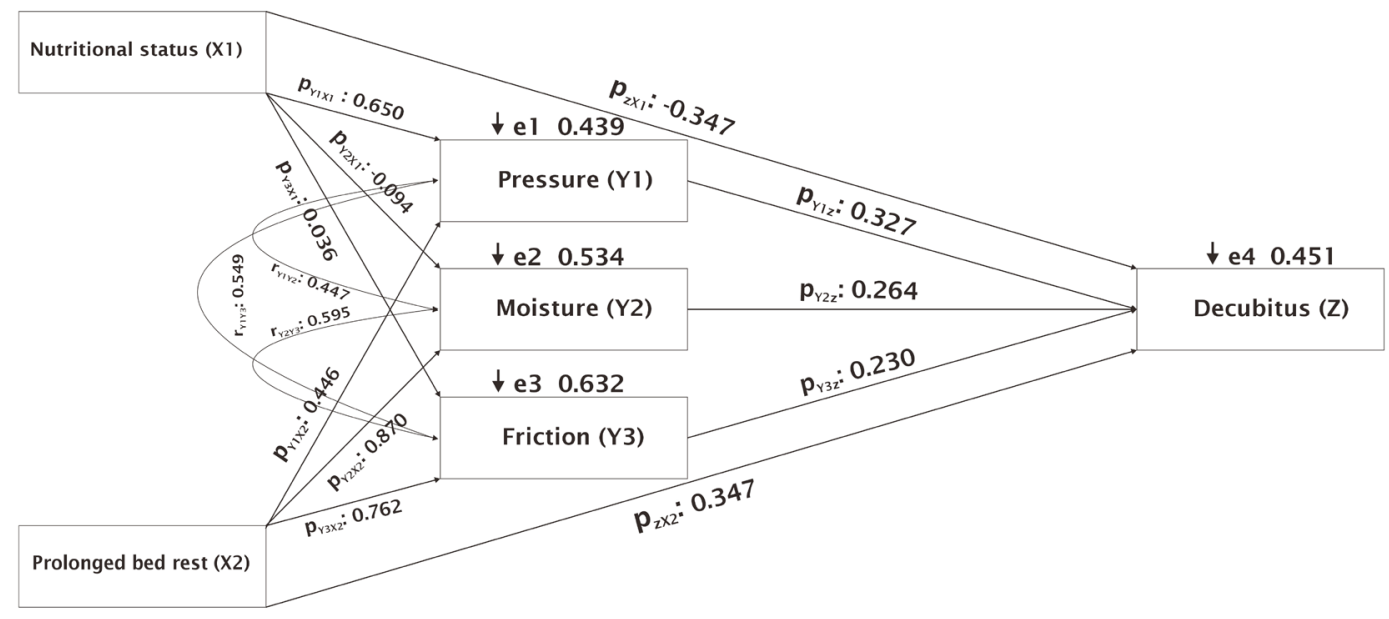

Figure 1. Path diagram [18], the effect of nutrition, and duration of bed rest on pressure, humidity, and friction and its effect on the incidence of decubitus

$p$ - path coefficient is the direct effect of an exogenous variable on endogenous variables; $r$-correlation between variables; $e-$ residual is the effect of other unobserved variables and error calculation. 


\section{Discussion}

The results discovered that nutritional factors and duration of bed rest directly affected decubitus incidents $\left(p_{\mathrm{x} 12}:-0.347\right.$; $\left.p_{x z}: 0.347\right)$. However, nutritional factors and duration of bed rest also indirectly influenced decubitus incidents through pressure, humidity, and friction (e4: 0.451). Malnutrition and food deficiency were the main risk factors for the onset of decubitus [23]. Some studies have also revealed that weight loss and inadequate nutritional intake had a higher risk of decubitus [24-27]. A person with underweight due to malnutrition often experienced muscle atrophy and subcutaneous tissue. As a result, the tissue role as a cushion between the skin and bones was thin. Therefore, the effect of pressure increases on these tissues accelerated the onset of decubitus [28].

Weight loss in malnutrition patients was also associated with a decline in total protein, albumin, hemoglobin, electrolytes, and vitamins $[29,30]$. Total protein and hypoalbuminemia levels also correlated with the occurrence of decubitus [31]. Poor nutrition would disrupt fluid and electrolyte balance. The level of hypo protein and hypoalbuminemia reduced osmotic pressure, triggering displacement of the volume of extracellular fluid into the tissue, which affected to interstitial edema. Edema decreased the blood supply and oxygen in the tissues [14, 32]. A decline in oxygen supply accelerated tissue ischemia, which stimulated tissue injury [23].

This study also revealed an indirect effect of nutritional status and duration of bed rest on the occurrence of decubitus through a pressure factor $\left(p_{\mathrm{y} 12}: 0.327\right)$. This study discovered that improving nutritional status and length of bed rest would increase the pressure, which affected the incidence of decubitus. The study results support previous studies that found that obese patients were two times more at risk of experiencing decubitus than patients with normal weight [33]. Fat tissue could reduce decubitus at certain locations, especially on bone protrusions, because it worked as a cushion to protect the skin from pressure [34]. However, in moderate-to-severe obesity, fat tissue vascularisation was not good, and thus fat tissue and other underlying tissues were susceptible to damage due to ischemia [35].

Tissue damage occurred when the pressure on the capillaries was large and blocked the capillaries. If the pressure exceeded the norm (> $22.5 \mathrm{~mm} \mathrm{Hg}$ ), the capillaries would be closed, and vascularity to the tissue would be low, which triggered ischemia $[36,37]$. When the patient was lying down or sitting, the pressure moved to the protrusion of the bone. The longer the pressure, the greater the risk of skin damage.
This study discovered that the duration of bed rest contributed to a significant effect on skin moisture and friction $\left(p_{y_{2 \times 2}}\right.$ : $\left.0.870 ; p_{\mathrm{Y}_{3 \times 2}}: 0.762\right)$, while the nutritional factor did not significantly influence skin moisture and friction $\left(p_{\gamma_{2 \times 1}}:-0.094 ; p_{\gamma_{3 \times 1}}\right.$ : 0.036). However, both nutritional factors and duration of bed rest had an indirect effect on decubitus through the humidity and friction factor $\left(p_{\mathrm{Y} 22}: 0.264 ; p_{\mathrm{Y} 3 \mathrm{z}}: 0.230\right)$. The duration of bed rest is directly related to immobilization problems, as these patients tended to rest in bed longer than patients with no immobilization problem. Long bed rest would stimulate pressure, humidity, and friction between the skin and bedcovers, which affected decubitus.

Patients with immobilization problems also tended to experience incontinence. The incidence of decubitus in incontinent patients was higher than for patients with no incontinence, especially patients with faecal incontinence [8]. The results of previous studies also showed that there was a correlation between incontinence and skin moisture, which contributed to the occurrence of decubitus [38]. Skin exposed to urine, feces, or sweat for hours was more susceptible to irritation and damage. This might occur in people who often wear wet diapers for a longer period. Softened skin tended to be damaged [39]. Humidity might accelerate compressive wounds by increasing the coefficient of friction (COF) between the skin and textiles. Therefore, reducing the moisture of the patient's skin was the main step to prevent compressive wounds [40].

\section{Limitations of the study}

The number of samples in this study was not well calculated, and the researchers only analyzed the cases in the study location, neglecting the minimum sample size. To obtain satisfying results, samples should be above 100 .

\section{Conclusions and recommendations}

Nutritional status and bed rest have an effect on pressure, humidity, and friction, which increases the incidence of decubitus in older people who stay in a geriatric nursing home. The researcher advised the manager and health workers in the geriatric nursing home to pay attention to the nutritional status and length of bed rest of the elderly because poor nutritional status and long bed rest without changes in position could contribute to decubitus. Minimizing pressure by using a special decubitus mattress in immobilized patients, as well as reducing the skin's moisture in the elderly by changing diapers immediately, will reduce the effect of decubitus.

Source of funding: This work was funded from the resources of Universitas Muhammadiyah Purwokerto.

Conflicts of interest: The authors declare no conflicts of interest.

\section{References}

1. Boyko TV, Longaker MT, Yang GP. Review of the current management of pressure ulcers. Adv Wound Care 2018; 7(2): 57-67, doi: 10.1089/wound.2016.0697.

2. Shafipour V, Ramezanpour E, Gorji MAH, et al. Prevalence of postoperative pressure ulcer: a systematic review and meta-analysis. Electron Physician 2016; 8(11): 3170-3176, doi: 10.19082/3170.

3. Amir Y, Tan FES, Halfens R, et al. Pressure ulcer prevalence and care in Indonesian hospitals: a multicenter, cross-sectional evaluation using an extended donabedian model. Ostomy Wound Manag 2017; 63(2): 8-23.

4. Sari SP, Everink IH, Sari EA, et al. The prevalence of pressure ulcers in community-dwelling older adults: a study in an Indonesian city. Int Wound J 2019; 16(2): 534-541, doi: 10.1111/iwj.13081.

5. Chiari P, Forni C, Guberti M, et al. Predictive factors for pressure ulcers in an older adult population hospitalized for hip fractures: a prognostic cohort study. PLOS ONE 2017; 12(1): e0169909-e0169909, doi: 10.1371/journal.pone.0169909.

6. Bereded DT, Salih MH, Abebe AE. Prevalence and risk factors of pressure ulcer in hospitalized adult patients; a single center study from Ethiopia. BMC Res Notes 2018; 11(1): 847, doi: 10.1186/s13104-018-3948-7.

7. Jaul E, Barron J, Rosenzweig JP, et al. An overview of co-morbidities and the development of pressure ulcers among older adults. $B M C$ Geriatr 2018; 18(1): 305, doi: 10.1186/s12877-018-0997-7. 
8. Lachenbruch C, Ribble D, Emmons K, et al. Pressure ulcer risk in the incontinent patient: analysis of incontinence and hospital-acquired pressure ulcers from the International Pressure Ulcer Prevalence ${ }^{\mathrm{TM}}$ Survey. J Wound Ostomy Cont Nurs 2016; 43(3): 235-241, doi: 10.1097/WON.0000000000000225.

9. Guy H. Preventing pressure ulcers: choosing a mattress. Prof Nurse 2004; 20(4): 43-46.

10. Shi C, Dumville JC, Cullum N. Support surfaces for pressure ulcer prevention: a network meta-analysis. PLOS ONE 2018; 13(2): e0192707-e0192707, doi: 10.1371/journal.pone.0192707.

11. Taylor C. Importance of nutrition in preventing and treating pressure ulcers. Nurs Older People 2017; 29(6): 33-39, doi: 10.7748/ nop.2017.e910.

12. Ghozali I. Model Persamaan Struktural, Konsep dan Aplikasi dengan Program AMOS 16.0. Semarang: Badan Penerbit Universitas Diponegoro; 2008 (in Indonesian).

13. Gavriilidou NN, Pihlsgård M, Elmståhl S. High degree of BMI misclassification of malnutrition among Swedish elderly population: ageadjusted height estimation using knee height and demispan. Eur J Clin Nutr 2015; 69(5): 565-571, doi: 10.1038/ejcn.2014.183.

14. Agrawal K, Chauhan N. Pressure ulcers: back to the basics. Indian J Plast Surg 2012; 45(2): 244-254, doi: 10.4103/0970-0358.101287.

15. Constantin M-M, Poenaru E, Poenaru C, et al. Skin hydration assessment through modern non-invasive bioengineering technologies. Maedica (Buchar) 2014; 9(1): 33-38.

16. Bergstrom N, Braden BJ, Laguzza A, et al. The Braden Scale for Predicting Pressure Sore Risk. Nurs Res 1987; 36(4): $205-210$.

17. Streiner DL. Finding our way: an introduction to path analysis. Can J Psychiatry. 2005; 50(2): 115-22, doi: 10.1177/070674370505000207.

18. Siswono Haryono PW. Structural Equation Modeling Untuk Penelitian Manajemen Menggunakan Amos 18.00. Bekasi: PT. Intermedia Personalia Utama; 2012 (in Indonesian).

19. Sarwono J. Path Analysis dengan SPSS: Teori, Aplikasi, Prosedur Analisis untuk Riset Skripsi, Tesis, dan Disertasi. Jakarta: Alex Media Komputido; 2012 (in Indonesian).

20. MacCallum RC, Browne MW, Sugawara HM. Power analysis and determination of sample size for covariance structure modeling. Psychol Methods 1996; 1(2): 130-149. Available from URL: http://ww.w.statpower.net/Content/312/Handout/MacCallumBrowneSugawara96.pdf.

21. Hu L, Bentler PM. Cutoff criteria for fit indexes in covariance structure analysis: conventional criteria versus new alternatives. Struct Equ Model A Multidiscip J 1999; 6(1): 1-55, doi: 10.1080/10705519909540118.

22. Kline RB. Principles and practice of structural equation modeling. 4th ed. New York: The Guilford Press; 2015.

23. Saghaleini SH, Dehghan K, Shadvar K, et al. Pressure ulcer and nutrition. Indian J Crit Care Med 2018; 22(4): 283-289, doi: 10.4103/ ijccm.IJCCM_277_17.

24. Horn SD, Bender $\mathrm{SA}$, Ferguson $\mathrm{ML}$, et al. the national pressure ulcer long-term care study: pressure ulcer development in long-term care residents. J Am Geriatr Soc 2004; 52(3): 359-367, doi: 10.1111/j.1532-5415.2004.52106.x.

25. Guenter P, Malyszek R, Bliss DZ, et al. Survey of nutritional status in newly hospitalized patients with stage III or stage IV pressure ulcers. Adv Skin Wound Care 2000; 13(4 Pt 1): 164-168.

26. Mathus-Vliegen EMH. Clinical observations: nutritional status, nutrition, and pressure ulcers. Nutr Clin Pract 2001; 16(5): 286-291, doi: $10.1177 / 088453360101600505$.

27. Tsaousi G, Stavrou G, loannidis A, et al. Pressure ulcers and malnutrition: results from a snapshot sampling in a university hospital. Med Princ Pract 2015; 24(1): 11-16, doi: 10.1159/000368360.

28. Kottner J, Gefen A, Lahmann N. Weight and pressure ulcer occurrence: a secondary data analysis. Int J Nurs Stud 2011; 48(11): 1339-1348 , doi: 10.1016/j.ijnurstu.2011.04.011.

29. Neloska L, Damevska K, Nikolchev A, et al. The association between malnutrition and pressure ulcers in elderly in long-term care facility. Open Access Maced J Med Sci 2016; 4(3): 423-427, doi: 10.3889/oamjms.2016.094.

30. Sternal D, Wilczyński K, Szewieczek J. Pressure ulcers in palliative ward patients: hyponatremia and low blood pressure as indicators of risk. Clin Interv Aging 2016; 12: 37-44, doi: 10.2147/CIA.S122464.

31. Serra R, Caroleo S, Buffone G, et al. Low serum albumin level as an independent risk factor for the onset of pressure ulcers in intensive care unit patients. Int Wound J 2014; 11(5): 550-553, doi: 10.1111/iwj.12004.

32. Gounden V, Jialal I. Hypoalbuminemia. Treasure Island (FL): StatPearls Publishing; 2018. Available from URL: https://www.ncbi.nlm. nih.gov/books/NBK526080/.

33. Hyun S, Li X, Vermillion B, et al. Body mass index and pressure ulcers: improved predictability of pressure ulcers in intensive care patients. Am J Crit Care 2014; 23(6): 494-501, doi: 10.4037/ajcc2014535.

34. Compher C, Kinosian BP, Ratcliffe SJ, et al. Obesity reduces the risk of pressure ulcers in elderly hospitalized patients. Journals Gerontol Ser A 2007; 62(11): 1310-1312, doi: 10.1093/gerona/62.11.1310.

35. Cai S, Rahman M, Intrator O. Obesity and pressure ulcers among nursing home residents. Med Care 2013; 51(6): 478-486, doi: 10.1097/MLR.0b013e3182881cb0.

36. Shore AC. Capillaroscopy and the measurement of capillary pressure. Br J Clin Pharmacol 2000; 50(6): 501-513, doi: 10.1046/j.13652125.2000.00278.x

37. Liao F, Burns S, Jan Y-K. Skin blood flow dynamics and its role in pressure ulcers. J Tissue Viability 2013; 22(2): 25-36, doi: 10.1016/j. jtv.2013.03.001.

38. Beeckman D, Van Lancker A, Van Hecke A, et al. A systematic review and meta-analysis of incontinence-associated dermatitis, incontinence, and moisture as risk factors for pressure ulcer development. Res Nurs Health 2014; 37(3): 204-218, doi: 10.1002/nur.21593.

39. InformedHealth.org. Pressure ulcers: overview. Cologne (Germany): Institute for Quality and Efficiency in Health Care; 2018. Available from URL: https://www.ncbi.nlm.nih.gov/books/NBK326428/.

40. Schwartz D, Magen YK, Levy A, et al. Effects of humidity on skin friction against medical textiles as related to prevention of pressure injuries. Int Wound J 2018; 15(6): 866-874, doi: 10.1111/iwj.12937.

Tables: 0

Figures: 1

References: 40

Received: 3.07 .2019

Reviewed: 4.08.2019

Accepted: 11.09 .2019
Address for correspondence:

Agus Santosa, MSc

Department of Medical Surgical Nursing, Health Faculty

Universitas Muhammadiyah Purwokerto

Jl. Raya Dukuhwaluh po. box 202

Purwokerto 53182

Indonesia

E-mail: agussantosa@ump.ac.id 